\title{
Colonial Courts and Secured Credit: Early American Commercial Litigation and Shays' Rebellion
}

\author{
Claire Priest
}

There is a peculiar inconsistency within current legal scholarship concerning the role of the courts in commercial relationships during the colonial period. Colonial legal scholars universally recognize that debt litigation ending in default judgments overwhelmed the caseload of colonial courts. At issue, however, is whether this high level of uncontested cases reflects a rationally organized effort of creditors and debtors to endow credit agreements with greater security, or whether these uncontested cases represent efforts to collect after real defaults and, thus, are evidence of widespread colonial insolvency.

Recent colonial law scholarship asserts that creditors and debtors used litigation as a means of endowing credit agreements with greater security. ${ }^{1}$ Colonial legal scholars found that the percentage of cases ending in default judgments increased dramatically in the 1720s and 1730s and remained at very high levels throughout the eighteenth century. ${ }^{2}$ When debtors did not default, they often confessed judgment against themselves, conceding responsibility for their debt. ${ }^{3}$ The prevailing interpretation today among colonial scholars is that the rise in uncontested debt cases and confessions of judgment by debtors is evidence of creditors and debtors using the court system as a rational mechanism to record debts. Creditors brought suit against debtors because becoming judgment creditors secured their interest in debtors' property by allowing quick execution at their discretion. The high level of uncontested cases and confessions of judgment represent voluntary debtor participation in the system: Debtors acquiesced to the entry of judgments against them (by default) because they too benefited from the bureaucratization of credit. Thus, according to the current

1. For a more detailed explanation of the current scholarship, see infra notes 19-35 and accompanying text.

2. See infra note 22 .

3. See infra note 23 and accompanying text. 
interpretation, the increase in uncontested debt litigation indicates not an increase in underlying disputes or in economic distress, but rather the creation of a modernized mechanism for debt recording, similar in kind to today's perfection of security interests through Article 9 of the Uniform Commercial Code. This view will be termed here the "debt-recording interpretation" of colonial litigation.

Yet, while the debt-recording interpretation of colonial courts is the dominant explanation of default judgments in current colonial law scholarship, other evidence characterizes the operations of the colonial court system in a dramatically different way. In 1786 and 1787, shortly after the Revolution, Shays' Rebellion constituted a widespread attack on the structure of the colonial court system, culminating in the violent takeover and closing of many county courts in western Massachusetts and throughout New England. The Shaysites (who referred to themselves as "Regulators") raised an armed revolt against the colonial court system. They condemned its injurious costliness, its fee structure which, they claimed, enabled judges, witnesses, and sheriffs to profit at the expense of litigants, and its cooptation by lawyers. ${ }^{4}$

Defenders of the regime dismissed the Regulators as "men in distress involved in debt and discontented" 5 and desiring "equal distribution of property," and "the annihilation of debts." Several of the Regulators' principal court reform proposals, however, were designed chiefly to reduce costs and administer justice more effectively. Indeed, although some Regulator proposals were clearly radical—such as to entirely abolish the courts of common pleas - others were more moderate. One Regulator proposed adopting a system according to which creditors and debtors could inexpensively record and secure debts, for example, by substituting the common pleas courts with "courts of record" that would specifically provide a debt-securing and recording service. ${ }^{8}$ Others proposed that the Massachusetts General Court enact legislation to provide for an inexpensive process to record debts within the common pleas system. The General Court responded by enacting the Confession Act of $1786,{ }^{9}$ which allowed

4. For histories of the Rebellion, see DAVID P. SZATMARY, SHAYS' REBELlion: THE MAKING OF AN AGRARIAN INSURRECTION (1980); and ROBERT J. TAYLOR, WESTERN MASSACHUSETTS IN THE REVOLUTION (1954). Shays' Rebellion is discussed in greater detail infra Part IV.

5. Letter from William Plumer to John Hale (Aug. 13, 1786), in 11 PUblications Colonial SOC'Y MASS. 386, 386 (1910).

6. Letter from William Plumer to John Hale (Sept. 20, 1786), in 11 PUBliCATIONS Colonial SOC'Y MASS. 390, 392 (1910).

7. See, e.g., TAYLOR, supra note 4, at 135 (citing Honestus, INDEP. CHRON. (Boston), June $15,1786)$.

8. See id. at $198 \mathrm{n} .21$ (citing Newton, INDEP. CHRON. (Boston), June 8, 1786).

9. 1786-1787 Mass. Acts 105-11, ch. 43. For a more detailed discussion of the Act, see infra notes 137-141 and accompanying text. 
debtors to avoid costly litigation in any debt case by "confessing" judgments against themselves to a justice of the peace for a small fee.

There is therefore a deep incompatibility between the debt-recording interpretation of colonial courts and the apparent motivations for Shays' Rebellion. The incompatibility is reflected not only in the Regulators' revolt against what they claimed to be a destructively inefficient court system, but also in the nature of the reforms enacted to quell the Regulators' demands. If colonial courts functioned in the eighteenth century as efficient modern-like debt-recording institutions, what motivated the Regulators to armed rebellion against their operation? Similarly, the General Court enacted the Confession Act to increase the efficiency of debt collection by permitting creditors to record debts cheaply in advance of execution. ${ }^{10}$ Why would a principal reform of the 1780 s advance the judicial system in the direction of a recording institution if, as colonial scholars suggest, that system had been made operational over fifty years before? Accounts of Shays' Rebellion cast doubt on the existence of an institutionalized recording system in Massachusetts during the colonial period and suggest, as a general matter, that colonial courts were far more costly and inefficient than colonial legal scholars have described.

These questions are central to understanding how the administration of colonial courts could provoke armed rebellion against the government as well as the role of colonial courts in enforcing commercial transactions. The principal ambition of institutions providing for debt securing and recording is to reduce the cost of credit: first, by generating information that will increase creditors' certainty about their chances of repayment and, second, by reducing the costs of executing on debtors' possessions upon default. Toward this end, a well-functioning debt-recording system should make available information about existing claims on debtors' property, enforce a priority-collection system - assuring creditors of their position in obtaining debtors' assets - and, by recording debts, generate evidence to substantiate claims of default to lower collection costs. ${ }^{11}$ Greater security leads to credit at lower prices. ${ }^{12}$

10. The General Court's intent is clear from the Act's title, "An Act for Rendering Process in Law Less Expensive." See 1786-1787 Mass. Acts 105, ch. 43.

11. See Alan Schwartz \& Robert E. SCOTT, COMmERCial Transactions 546-48, 565 (2d ed. 1991) (discussing the general ambitions of the Uniform Commercial Code's system of recording and securing credit). Legal scholars have questioned the extent to which the UCC's secured credit regime increases economic welfare principally because secured credit may simply benefit secured creditors at the expense of unsecured creditors. For a general review of both theories and criticisms of secured credit, see DOUglas G. BAIRD \& THOMAS H. JACKSON, SECURITY INTERESTS IN PERSONAL PROPERTY: CASES, PROBLEMS, AND MATERIALS 316-42 (2d ed. 1987); and Alan Schwartz, Security Interests and Bankruptcy Priorities: A Review of Current Theories, 10 J. LEGAL STUD. 1 (1981).

12. See SCHWARTZ \& SCOTT, supra note 11, at 546; Douglas G. Baird \& Thomas H. Jackson, Possession and Ownership: An Examination of the Scope of Article 9, 35 STAN. L. REV. 
Thus, it is central to our understanding of colonial law to determine whether, as a debt-collecting institution, colonial courts were wellfunctioning and modernized or inefficiently costly and operating to the benefit of judges, sheriffs, and lawyers at the expense of the citizenry. Moreover, debt cases dominated civil court dockets throughout the colonial period. ${ }^{13}$ While it is accepted that, during the nineteenth century, courts affected the American economy through their articulation of the law of torts, contracts, and statute-based legal fields such as corporations, during the colonial period, in contrast, the judiciary affected economic development principally through its enforcement of credit relationships. ${ }^{14}$

It is not useful to evaluate judicial "efficiency" in the abstract. This Note presents an empirical examination of the nature of default judgments and confession of judgment cases in the colonial courts. It attempts to determine whether these cases represented creditors and debtors using litigation to record debts or, instead, actual defaults by debtors. Toward that end, it analyzes two empirical and legal dimensions of judicial operations that have not been adequately explored. First, there is a sharp difference between the characterization by colonial scholars of the courts as a modernized bureaucracy and by the Regulators as a costly and burdensome institution chiefly benefiting the legal officers who managed it. Neither account to date has carefully examined the fee structure of colonial courts and measured the magnitude of court fees imposed in each case against the magnitude of debt to be collected.

Second, according to the debt-recording interpretation, litigation occurred not when a debt was due, nor when a creditor wanted to execute on a debtor's possessions, but immediately after the creditor extended credit, in order to record the debt. ${ }^{15}$ In contrast, the Regulators' complaints

175,175 (1983) ("To the extent that the creditor is uncertain about the priority of his security interest, and thus about whether he will recover his loan in full if the debtor defaults, he will require a higher interest rate from the debtor.").

13. William E. Nelson found that debt cases constituted $74 \%$ of all cases heard during the period 1725 to 1774 in the Plymouth, Massachusetts County Court of Common Pleas, the court of original jurisdiction for civil lawsuits. See William E. NELSON, DisPuTE AND CONFLICT RESOLUTION IN PLYMOUTH COUNTY, MASSACHUSETTS, 1725-1825, at 23-24 (1981).

14. Colonial legal historians of the last generation have universally agreed on the importance of debt to an understanding of colonial law and its impact on the colonial economy. See, e.g.,

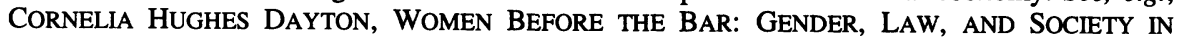
CONNECTICUT, 1639-1789, at 70 (1995) ("The area of law that touched the most people in early New England was, not crime, but civil litigation, especially suits for debt.”); BRUCE H. MANN, NEIGHBORS AND STRANGERS: LAW AND COMMUNTTY IN EARLY CONNECTICUT 8 (1987) (discussing the "overwhelming predominance of debt cases in civil litigation" in the colonial period); A.G. ROEBER, FAITHFUL MAGISTRATES AND REPUBLICAN LAWYERS: CREATORS OF VIRGINIA LEGAL CULTURE, 1680-1810, at 39-41 (1981) (focusing on the " 'tissue of debt' that enmeshed all of Virginia's planters"); Deborah A. Rosen, Courts and Commerce in Colonial New York, 36 AM. J. LEGAL HIST. 139, 140 (1992) (characterizing the nonpayment of debts as the "quintessential legal injury" of the 18th century).

15. See infra notes 29-32. 
imply that debt litigation was real, not nominal, and represented the palpable prospect of paying high costs and losing property, suggesting that creditors litigated after other attempts to collect against debtors had failed. These contrasting characterizations suggest a substantial difference in timing from the date that credit was extended until the date of litigation. Again, neither account to date has carefully examined the timing of debt litigation.

This Note evaluates these different interpretations of the operation of the colonial courts, relying on an empirical study of over 5000 cases in the Plymouth, Massachusetts County Court of Common Pleas, ${ }^{16}$ during the years 1724 to 1750 and 1781 to $1795 .{ }^{17}$ It examines for sample years the relationship between judicial fees and the level of underlying debt. Second, the Note measures the time between the extension of credit and debt litigation for all 5048 cases. The data suggest the need to reassess colonial courts' role in debt collection.

First, the data show that Massachusetts's court fees were extremely high, comprising a substantial portion of the median debt even when a creditor simply obtained a default judgment. This finding alone casts doubt on the characterization of colonial courts as efficient and well-functioning. Moreover, following the English rule, civil litigation in the colonies operated on a strict loser-pays fee system. Thus, in default and confession of judgment cases, the entirety of the large fees associated with debt collection through the courts was paid by debtors. The English-rule fee system has been neglected in colonial historians' interpretations of debt litigation. It suggests skepticism, however, about the claim that debtors voluntarily confessed debt to facilitate efficient debt administration.

The Plymouth County data also show that the period of time between execution of a loan and litigation to collect the debt was characterized by wide variance, rather than by the uniformity suggested by the debtrecording interpretation of colonial litigation. Indeed, the number of instances in which litigation was filed at or shortly after loan execution was very small, exactly in contrast to the current interpretation.

As I shall show, the high cost of litigating in colonial Massachusetts suggests an explanation for the wide variance in the timing of litigation: High court fees created a disincentive to sue until creditors learned that their debtors might default. Thus, the imposition of high fees in colonial courts prevented the use of litigation as a modern recording device. This

16. See 1-10 PlymOUTH COURT RECORDS, 1686-1859 (David Thomas Konig ed., 19781980) [hereinafter PLYMOUTH COURT RECORDS]. For a discussion of the publication of the court records and the representativeness of Plymouth County within New England, see William E. Nelson, Introduction to 1 PLYMOUTH COURT RECORDS, supra.

17. For an explanation of why these periods were chosen and a more detailed description of the empirical study, see infra notes 82-85 and accompanying text. 
Note presents evidence on actual litigation timing that suggests, instead, that creditors typically sued six to nine months after default, evidence of real economic distress.

The high costs of colonial debt-administration and the forces influencing the timing of debt litigation imply a deeper understanding of the background and motivation for Shays' Rebellion. Although creditors had an incentive to postpone litigation under stable economic conditions, widespread insolvency and uncertainty during the postwar recession of 1783 to 1785 , which may have rivaled the Great Depression in severity, ${ }^{18}$ propelled creditors to the courts in droves. High court fees meant that litigation to collect subjected debtors to obligations vastly increased over their original debts. Shays' Rebellion, thus, was triggered by the recession and an inefficient and expensive court process. The Massachusetts General Court enacted reforms in response to Shays' Rebellion that were specifically designed to encourage creditors to record debts. The introduction of these procedural reforms in the 1780s suggests their absence in the earlier colonial period.

The empirical and legal findings of this Note suggest a new interpretation of colonial courts' role in commercial transactions. Colonial legal scholars have correctly described litigation as a means of endowing credit agreements with greater security, but they have neglected a crucial empirical point. In Massachusetts, the high fees of colonial courts deterred creditors from litigating until they believed that their debtors would actually default. As a result, colonial creditors and debtors, as a general matter, incurred the costs that debt-recording systems such as the modern UCC reduce and eliminate: the costs of gathering information about debtors' other debts, a reduction in the supply of credit because of creditors' uncertainty about their priority with respect to other creditors, and the expenses of litigating when creditors feared that they would not otherwise be repaid. Moreover, the inefficiencies of the colonial courts suggest that the Shaysites' concerns with the court system were entirely legitimate.

Part I describes in more detail the current scholarship on the colonial court system and the debt-recording interpretation of the rise in uncontested debt litigation. Part II assesses the impact of litigation costs on colonial debtors. Part III analyzes economic considerations influencing a creditor's decision to litigate. Part III also presents the Plymouth County empirical data showing the actual timing of debt litigation. On the basis of this understanding of the colonial courts, Part IV, then, turns to Shays' Rebellion. Sections A and B describe economic conditions and remedial legislation preceding Shays' Rebellion. Section $C$ analyzes the impact of recession conditions on litigation. Section $D$ describes the legislative 
attempts to institute a debt-recording system in response to Shays' Rebellion. Finally, Part V discusses the implications of the lack of a debtrecording system to an understanding of colonial courts' role in commercial relationships.

\section{DEBT LITIGATION IN THE EIGHTEENTH CENTURY: MODERNIZATION AND THE DEBT-RECORDING INTERPRETATION}

Recent colonial law scholarship, most prominently Bruce Mann's Neighbors and Strangers, emphasizes that the legal system transformed in the first half of the eighteenth century to provide conditions for greater commercialization and economic development. The law transformed, according to Mann, in response to an expansion of trade relations accompanying population growth, military expeditions, agricultural specialization, and greater monetization of the economy through government paper-money issues. ${ }^{19}$ In the first decades of the eighteenth century, colonists, when extending credit, increasingly relied on signed and sealed credit instruments, particularly conditional bonds and promissory notes. Mann found that greater reliance on notes and bonds coincided with an exponential increase in debt litigation volume, above increases in population, and that most of the cases contributing to the litigation increase were cases ending in default judgments. ${ }^{20}$ By 1730 , the Hartford Inferior Courts of Common Pleas ${ }^{21}$ entered judgments in favor of creditors in over $90 \%$ of debt cases by default - with no appearance by the debtor. ${ }^{22}$ When defendant debtors did appear, they often confessed judgment against themselves. ${ }^{23}$

The prevailing explanation of the increase in litigation generally and of the specific increase in uncontested debt cases derives from the hypothesis that the courts were transforming to promote commercialization. Legal historians interpret the rise in cases where debtors defaulted or confessed judgment as evidence of increased credit opportunities and economic advance. According to Mann:

19. See MANN, supra note 14 , at 31 .

20. See id. at 27-41.

21. The Inferior Courts of Common Pleas had original jurisdiction over all civil matters concerning amounts greater than 40 shillings in which the Crown was not a plaintiff and, thus, were the principal fora for initiating private debt actions. See WILliam E. NELSON, AMERICANIZATION OF THE COMMON LAW: THE IMPACT OF LEgal CHANGE ON MASSACHUSETTS SOCIETY, 1760-1830, at 15-16 (1975).

22. Mann found that the percentage of uncontested cases on written instruments in the Hartford County Court rose from $60 \%$ in 1700 and 1710 , to $70.8 \%$ in 1720 , and to $95.6 \%$ in 1730 , remaining in the $90 \%$ range thereafter. See MANN, supra note 14, at 172 tbl.2. Dayton's study of the New Haven County Court revealed that, during the period 1770 to 1773,342 of $385(89 \%)$ of all debt cases were uncontested. See DAYTON, supra note 14, at 100 tbl.3.

23. See MANN, supra note 14 , at 39-40. 
Commercial expansion brought with it-indeed, rode the crest ofa rising tide of indebtedness. ... The sharp increase in uncontested debt actions in the 1730s, in particular the sudden tendency of debtors to confess judgment against themselves to facilitate collection by their creditors should they fail to repay, underscored not only the massive increase in indebtedness but also the acceptance of indebtedness as a necessary cost of doing business. ${ }^{24}$

Cases ending in default judgments and confessions of judgment signal commercialization because this litigation was intended to generate more secure credit agreements, not to resolve disputes. A "judgment creditor" could more easily execute on a debtors' possessions and, thus, had greater security of repayment. Widespread use of litigation in this way turned the courts into a recording system and represented "the emergence of a culturally powerful, formalistic, rationalized legal system." 25

The debt-recording interpretation has two implications. First, historians assert that the entry of default judgments represents an agreement by debtors to be sued as an element of the bargain to receive credit. Debtors conceded liability because creditors with greater security would extend credit at lower interest rates. ${ }^{26}$ According to Mann, "credit had become something extended in single transactions in return for formal admissions of liability." ${ }^{27}$ Although Deborah Rosen views the nature of default judgments as a perplexing historical problem, she suggests that debt lawsuits may have been brought "collusively, that is, with the consent of the defendant-debtor, as a way of securing the debt." 28

Second, creditors brought suit on debt instruments before they intended to collect the debt, which is to say that they sued in order to secure the debt against other creditors, not to demand payment. According to Mann, "[a]ll of the confessions of judgment and an indeterminate number of the defaults represent creditors reducing the debts to judgments before they had any intention of trying to collect from the debtor." ${ }^{29}$ Cornelia Dayton concurs, noting that " $[t]$ he predictability of getting a judgment [on signed credit instruments] .... turned eighteenth-century debt litigation into a recording

24. Id. at 62; see also DAYTON, supra note 14, at 90, 102 (interpreting increased debt litigation as evidence of an expansion of credit and commercialization); Rosen, supra note 14, at 142 (same).

25. Cornelia Dayton, Law and Disputing in Commercializing Early America, 87 MiCH. L. REV. 1538, 1543 (1989) (reviewing MANN, supra note 14).

26. See supra note 12 and accompanying text.

27. MANN, supra note 14 , at 40 .

28. Deborah A. Rosen, The Supreme Court of Judicature of Colonial New York: Civil Practice in Transition, 1691-1760, 5 LAW \& HIST. REV. 213, 233 (1987). Rosen suggests that the high rate of uncontested cases may also either represent real defaults, as is examined here, or creditors suing to avoid a six-year statute of limitations. See id.

29. MANN, supra note 14 , at 40 . 
device:... creditors waited to execute those easily won judgments until they wished to call in the debt." ${ }^{30}$

Although the scholars advancing the debt-recording interpretation of colonial litigation have not addressed these questions directly, there are three clear empirical implications of the theory. First, the historians imply that the court fees associated with debt litigation were modest in comparison to the debt; otherwise, creditors and debtors would not agree to the process. It would be inconsistent with the interpretation to find that court fees constituted an abnormally large percentage of debt, inflicted on one transacting party to his or her detriment.

In addition, the debt-recording interpretation implies that litigation to enforce the debt was brought at the time that the debt was executed or shortly thereafter. The essential ambition of debt recordation, obviously, is to establish a legal priority to the debtor's assets. As a consequence, there is no purpose in delay; indeed, delay of any period reduces the value of the debt by affording an opportunity for other creditors to establish claims prior or equivalent to the previously extended debt. Thomas Russell's recent study of nineteenth-century debt litigation in South Carolina extends the influence of the debt-recording interpretation in this respect. Russell reveals that, by the mid-nineteenth century, creditors filed suit, obtained judgments against debtors, and executed on debtors' possessions on the same day that they entered debt agreements. ${ }^{31}$ In Russell's account, creditors used litigation to establish priority over other creditors, rather than to collect against the debtor. Russell relies on Mann's "recording mechanism" interpretation to conclude that concomitance of litigation and lending originated in the middle of the eighteenth century. ${ }^{32}$ Thus, it would be inconsistent with the debt-recording interpretation to find substantial periods of time between execution of the debt and litigation to collect it.

Third, there is a fundamental incompatibility between the debtrecording interpretation of litigation and the Regulators' attack of the court system as costly, inefficient, and lacking a mechanism by which creditors and debtors could inexpensively secure debts. If court fees imposed huge burdens on debtors, then the courts were less efficient than recent

30. DAYTON, supra note 14 , at 91 ; see also id. at 102 ("Debt litigation had become a recording device for the easy credit available to propertied and professional men, craftsmen, and entrepreneurs eager to expand their landholdings and businesses."); Rosen, supra note 28, at 234 (referring to colonial debt litigation as a "recording device").

31. See Thomas D. Russell, The Antebellum Courthouse as Creditors' Domain: Trial-Court Activity in South Carolina and the Concomitance of Lending and Litigation, 40 AM. J. LEGAL HIST. 331 (1996).

32. See id. at 362-63 ("By the middle of the eighteenth century in Connecticut, patterns of litigation resembled, in broad outline, those of antebellum South Carolina. . . . Mann's creditors of the mid-eighteenth century did routinely secure judgments through either confessions or default judgments in order to expedite their access to debtors' property in the event of default."). 
scholarship suggests. Moreover, these fees would lead to even greater burdens on debtors during periods of recession, when insolvency and uncertainty drove creditors to litigate despite the tremendous cost imposed on debtors further imperiling collection of the debt. The incompatibility between the account of colonial courts in legal scholarship and the Regulators' protests raises questions about the applicability of the debtrecording interpretation, at least to Massachusetts, ${ }^{33}$ and, indeed, about the broader role of the court system in commercial relationships. ${ }^{34}$

Aside from Russell, these empirical implications of the debt-recording interpretation of colonial litigation have not been studied and, including Russell, never from eighteenth-century data. Nor have legal historians systematically examined the broader question of what determines a creditor's choice to sue given the characteristics of the colonial legal system. ${ }^{35}$ The following Parts of this Note empirically examine the implications of the debt-recording interpretation and litigation trends preceding Shays' Rebellion as a means of analyzing the nature of the colonial courts and litigation.

\section{ThE COSTLINESS OF COLONIAL DEBt Litigation}

A central element of the interpretation of colonial debt litigation as serving a modern recording function is the assumption that debtors acquiesced to default judgments against themselves because they benefited, perhaps through lower interest rates, from a more rational administration of credit. No legal historian thus far has analyzed the costliness of colonial debt litigation empirically. This Part describes the structure of the colonial fee system and uses court records and wage data to assess the impact of court fees on debtors facing litigation. Section A describes the structure of colonial court fees. Section B presents the empirical data relating court fees to the magnitude of underlying debt and to colonial wage levels.

33. Each colony had an independent legal system. This study focuses on Massachusetts. Mann's, Dayton's, and Rosen's studies focus on Connecticut and New York. Precise comparisons between colonies have yet to be made.

34. In addition, closer attention to economic scholarship raises doubt about the conception that legal developments propelled economic growth during the colonial period. See, e.g., JAMES A. HENRETTA, Wealth and Social Structure, in THE ORIGINS OF AMERICAN CAPITALISM: COLLECTED ESSAYS 148, 166-67 (1991) (finding that, although there is variation between economists' studies, all current scholarship places annual per capita growth rates in the New England colonies within the range of 0.2\%-0.5\%); JOHN J. MCCUSKER \& RUSSELL R. MENARD, THE ECONOMY OF BRITISH AMERICA, 1607-1789, at 280 tbl.13.1 (1991) (finding no substantial change in per capita exports from Great Britain to the New England colonies during the period 1767 to 1774). These studies have largely been neglected by colonial legal scholars.

35. But see Robert A. Kagan, The Routinization of Debt Collection: An Essay on Social Change and Conflict in the Courts, 18 LAW \& SOC'Y REV. 323 (1984) (including cost as a factor leading to changes in litigation rates in the 20th century). 


\section{A. The Fee Structure of Colonial Courts}

Colonial courts had a fee structure entirely different from ours today. First, litigants compensated the various actors in the judicial systemsheriffs, judges, clerks, and witnesses-for each service they performed. ${ }^{36}$ According to the 1742 Massachusetts fee schedule, for example, when initiating a suit in one of the inferior courts, plaintiffs paid the judge five shillings for entering the action and the constable six pence for serving the summons (and double all fees if the plaintiff was not a freeholder). ${ }^{37}$ Fee schedules required reimbursement for travel and a per-day attendance fee to all clerks, judges, constables, and witnesses. Litigants paid clerks for each page written, constables for each witness sworn, and the cryer for each jury called. ${ }^{38}$ Conclusion of the case led to additional charges, whether for the trial, for default or confession of judgment (six pence to the judges, six pence to the clerk for recording the outcome), or for imprisonment of the debtor (two shillings and six pence for "turning the key on each prisoner committed"). ${ }^{39}$ The colonial fee structure was regressive; costs were the same, no matter how large the amount in question. Moreover, colonial law

36. The court fee structure represented a standard means of payment for government services at the time. As described by Bernard Bailyn, government officials typically received compensation from "fees, bribes, and gifts," rather than salaries during the colonial period. Bernard BaIlyn, THE New England Merchants in the SEventeEnTH CENTURY 164 (1979). On colonial fee structure generally, see DAYTON, supra note 14, at 49; and Joseph H. Smith, Introduction to COLONIAL JUSTICE IN WESTERN MASSACHUSETTS (1639-1702): THE PYNCHON COURT RECORD 189-90 (Joseph H. Smith ed., 1961).

37. See 3 ACts AND Resolves, Public and PRIVAte, of the Province of MASSACHUSETTS BAY 13-18, ch. 5 (Boston, Wright 1878) [hereinafter 3 ACTS AND RESOLVES OF MASSACHUSETTS]. The Massachusetts courts' fee structure was revised repeatedly throughout the 17th and 18th centuries. See, e.g., 1 ACTS AND RESOlves, PUBliC AND PRIVATE, OF THE PROVINCE OF MASSACHUSETTS BAY 84-88, ch. 37 (Boston, Wright \& Potter 1869) (1692 fee schedule) [hereinafter 1 ACTS AND RESOLVES OF MASSACHUSETTS]; 3 ACTS AND RESOLVES OF MASSACHUSETTS, supra, at 101-07, ch. 10 (1743 fee schedule); id. at 176-81, ch. 13 (1744 fee schedule); id. at 328-33, ch. 24 (1747 fee schedule); id. at 525-31, ch. 8 (1751 fee schedule); id. at 656-66, ch. 28 (1753 fee schedule); id. at 1032-38, ch. 30 (1757 fee schedule); 5 ACTS AND Resolves, Public and PRIVATE, OF the PROVINCE OF MASSAChuSETtS Bay 486-95, ch. 23 (Boston, Wright \& Potter 1886) (1776 fee schedule) [hereinafter 5 ACTS AND RESOLVES OF MASSACHUSETTS]; id. at 761-70, ch. 17 (1778 fee schedule); 1782-1783 Mass. Acts 10-24, ch. 5 (1782 fee schedule); 1784-1785 Mass. Acts 458-62, ch. 18 (1785 fee schedule); 1786-1787 Mass. Acts 226-38, ch. 73 (1786 fee schedule). See generally TAYLOR, supra note 4, at 31 (describing fee schedule revisions). In 1728, and again in 1739, the General Court responded to the increase in the percentage of default judgments by granting more money per jury trial to jurors and witnesses. See 2 ACts AND Resolves, PUbliC AND PRIVATE, OF THE PROVINCE OF MASSACHUSETTS BAY at 463-64, ch. 10 (Boston, Wright \& Potter 1874) [hereinafter 2 ACTS AND RESOlVES OF MASSACHUSETTS]; id. at 938-39, ch. 4.

38. See 3 ACTS AND RESOLVES OF MASSACHUSETTS, supra note 37, at 16-17, ch. 5.

39. See id. at 17. 
defined court costs as well as attorneys' fees as an element of damages. As a consequence, the losing party bore the burden of paying all fees. ${ }^{40}$

Corrupt government officials, witnesses and jurors also may have increased fees from time to time. Abuse is evident, for example, in 1739 and 1745 Acts requiring that parties actually attend court to be compensated for attendance, and limiting the number of days people could "attend" court before filing their suits. ${ }^{41}$ The text of a 1737 Act prohibiting sheriffs from bringing lawsuits on behalf of creditors explicitly states that sheriffs had increased the litigation rate for their own gain. ${ }^{42}$ In response to complaints of abuse, a 1728 Act required winners of lawsuits to obtain approval on bills of costs before the court adjourned. ${ }^{43}$

Justices of the peace, also appointed by the governor, individually decided debt suits worth less than forty shillings. Justices of the peace offered a less formal and less expensive forum for obtaining judgments. They usually resided within the same town as the litigants, and heard cases year-round in their homes or in taverns. ${ }^{44}$ The fees of justices of the peace were also set by statute on a per-service basis, but were much lower than those of the county courts. ${ }^{45}$ Litigants could, however, appeal decisions of the justices of the peace to the common pleas courts, which would increase total litigation fees and delay the execution process. ${ }^{46}$

\section{B. Fees and Costs in Colonial Litigation}

How expensive was debt litigation in the colonial courts? Again, although scholars have not carefully examined the costs of colonial litigation, it is central-though implicit-to the debt-recording interpretation of the courts that overall litigation costs were relatively modest, especially in cases ending in default. According to the English rule, all court costs and fees were borne by the losing party. ${ }^{47}$ It can be assumed that a debtor would voluntarily agree to waive defenses only if the ensuing

40. See TAYLOR, supra note 4, at 30-31. For the English legislative history of the "loser pays" system, see 3 WILLIAM BLACKSTONE, COMMENTARIES ON THE LAWS OF ENGLAND *399400.

41. See 2 ACTS AND ReSOlVES OF MASSACHUSETTS, supra note 37, at 1005-06, ch. 14; 3 ACTS AND RESOLVES OF MASSACHUSETTS, supra note 37, at 248, ch. 7.

42. See 2 ACTS AND RESOLVES OF MASSACHUSETTS, supra note 37, at 794, ch. 3.

43. See id. at 492 , ch. 2.

44. See DAYTON, supra note 14 , at 38 .

45. For the statutes detailing fees of the justices of the peace, see supra note 37 and the sources cited therein. For my study of the fees of one justice of the peace, see infra text accompanying notes 60-62. As I shall describe infra Part IV, the principal proposal of Regulators urging the revamping of the colonial court system was to expand the jurisdiction of justices of the peace to reduce court fees.

46. See NELSON, supra note 21, at 15-16.

47. See supra note 40 and accompanying text. 
costs were modest in comparison to the gain achieved from the creditor, either in terms of a lower interest rate or a greater willingness to extend credit. Furthermore, the characterization of the colonial courts as regularized, modernized, or bureaucratized implies that the overall costliness of its operations were low.

This Section evaluates the costliness of the colonial courts by examining all uncontested cases brought on promissory notes and bonds in the Plymouth County Court of Common Pleas for two sample sessions, March 1740 and April 1783, ${ }^{48}$ two years in which Massachusetts experienced both severe recessions and high levels of uncontested debt litigation. ${ }^{49}$ The Massachusetts records include the actual aggregate fees imposed for each case. This Section evaluates litigation costliness in two ways. First, it measures, by case, court fees as a percentage of the underlying debt in the dispute. Second, it evaluates court fees on an absolute basis by comparing the average fees per case to various measures of workers' earnings during similar periods.

Table 1 shows fees as a percentage of underlying debt in debt cases ending in default for March 1740 and April 1783, respectively. The Table presents averages by case quartiles, ranging from that twenty-five percent of all cases involving the lowest debt amounts to that twenty-five percent involving the largest debt. The Table also shows the average and median percentage of fees to debt for all cases. ${ }^{50}$

48. The common pleas courts met four times a year in each county. I chose to examine the spring sessions in these sample years because more cases were litigated in winter and spring sessions than in the summer. See infra note 89 and accompanying text.

49. I chose 1783 as a representative pre-Shays' Rebellion year because in 1784 the Massachusetts General Court expanded the jurisdiction of justices of the peace over cases involving small debt amounts, see infra note 126 and accompanying text, which was likely to affect the relationship between fee levels and debt amounts. On recession and litigation conditions in 1783, see infra Part IV. For conditions in 1740, see MANN, supra note 14, at 62-63, which notes a decline in agricultural prices in 1740, and ROBERT ZEMSKY, MERCHANTS, FARMERS, AND RIVER GODS: AN ESSAY IN EIGHTEENTH-CENTURY AMERICAN POLITICS 117-26 (1971), which discusses the monetary crisis of the period.

50. For a discussion of how the sample was defined, see infra note 84 . 


\section{TABle 1: COURT FeES AS A PERCENT OF UNDERL YING DEBT IN CASES RESULTING IN DEFAULT: 1740, 1783}

\begin{tabular}{|c|c|c|c|c|}
\hline \multicolumn{3}{|c|}{$\begin{array}{l}\text { March } 1740 \\
\text { (130 Cases) }\end{array}$} & \multicolumn{2}{|c|}{$\begin{array}{c}\text { April } 1783 \\
\text { (154 Cases) }\end{array}$} \\
\hline $\begin{array}{c}\text { Debt Level } \\
\text { Quartile }\end{array}$ & $\begin{array}{l}\text { Debt Level } \\
\text { in English } \\
\text { Sterling }\end{array}$ & $\begin{array}{c}\text { Fees as \% } \\
\text { of Debt }\end{array}$ & $\begin{array}{l}\text { Debt Level } \\
\text { in English } \\
\text { Sterling }\end{array}$ & $\begin{array}{c}\text { Fees as \% } \\
\text { of Debt }\end{array}$ \\
\hline Lowest & $<£ 1.28$ & $79.0 \%$ & $<£ 4.08$ & $59.15 \%$ \\
\hline $3 r d$ & $£ 1.28-2.73$ & $29.6 \%$ & $£ 4.08-7.97$ & $24.8 \%$ \\
\hline $2 n d$ & $£ 2.73-5.36$ & $16.0 \%$ & $£ 7.97-17.39$ & $12.6 \%$ \\
\hline Highest & $>£ 5.36$ & $6.5 \%$ & $>£ 17.39$ & $5.1 \%$ \\
\hline \multicolumn{2}{|c|}{ Average all debts: } & $32.6 \%$ & & $25.5 \%$ \\
\hline \multicolumn{2}{|c|}{ Median: } & $21.7 \%$ & & $16.9 \%$ \\
\hline
\end{tabular}

As is evident from Table 1, during the colonial period, court fees for cases ending in default were extraordinarily high in comparison to underlying debt levels. Fees comprised a substantially higher percentage of lower debt amounts because they were fixed regardless of the magnitude of debt to be collected. ${ }^{53}$ Nevertheless, the figures are remarkable. In 1740 , for example, fees comprised an astounding $79 \%$ of debt for the lowest quartile of cases. As stated, the sample includes only default cases. Thus, for the cases regarding the smallest $25 \%$ of debts, debtors who did not appear were obliged to pay a $79 \%$ premium on top of the magnitude of outstanding debt.

51. All values were taken from the Plymouth Court Records and converted to English Sterling. The values of colonial currencies (which had English Sterling denominations although they were independent currencies) fluctuated wildly, particularly during colonial governments' experiments with paper money in the first half of the 18th century and during the Revolution. See JOHN J. MCCUSKER, MONEY AND EXCHANGE IN EUROPE AND AMERICA, 1600-1775: A HANDBOOK, 138-45 tbl.3.1 (1978). English Sterling values were more stable than those of colonial currencies during the 18th century, so conversion allows for more meaningful crosscomparisons over time. For the purposes of Table 1, I converted the 1740 values to English Sterling according to the schedule given in MCCUSKER, supra, at tbl.3.1.

52. Converting 1783 values to English Sterling is complex because historians have not yet determined the exact commercial exchange rate at the time. The confusion stems from the fact that in 1781 the infamous Continental bills were allowed to expire and sterling silver coins were briefly the principal money and unit of account in America before conversion to the dollar system. For a discussion of the expiration of the Continentals, see E. JAMES FERGUSON, THE POWER OF THE PURSE: A HISTORY OF AMERICAN PUBLIC FINANCE, 1776-1790, at 66-69 (1961). I deflated the values to Sterling using the par exchange rate, $£ 1337 \mathrm{~s}$. $6 \mathrm{~d}$. Massachusetts money equals $£ 100$ English Sterling. See MCCUSKER, supra note 51, at 120. This is the current best estimate of the exchange rate at the time. See E-mail from John J. McCusker to Claire Priest (Feb. 10, 1999) (on file with author).

53. In one case, fees alone were $158 \%$ of the debt. See Demount v. Leonard (Mar. 1740), in 6 PLYMOUTH COURT RECORDS, supra note 16, at 217 \#157. 
For larger debts, that percentage declined. But even in the second highest quartile, fees comprised $16 \%$ of outstanding debt. Table 1 shows that the average and median court fee percentages for all cases were a substantial $32.6 \%$ and $21.7 \%$, respectively.

Table 1 also shows that, for 1783, the fee proportions were lower than for 1740 , but still substantial. Thus, fees comprised $59.15 \%$ of the lowest quartile of cases, but still $12.6 \%$ of the second highest quartile, and $25.5 \%$ and $16.9 \%$ of the average and median case, respectively.

How expensive were the colonial courts on an absolute basis? Table 2 shows the relationship between the average fees for an uncontested debt case and various measures of contemporary wages. To make these calculations, I used the average and median fees of those cases examined in Table 1 and compared them to estimates of wages at approximately the same time..$^{54}$

TABle 2: Median AND Average Court FeEs in CASES Resulting IN DEFAULT AS COMPARED TO WAGES: 1735-1754, 1781-1782

\begin{tabular}{|c|c|c|c|}
\hline \multicolumn{2}{|c|}{ Wages 1735-1754 } & \multicolumn{2}{c|}{ Wages 1781-1782 } \\
\hline Occupation & Labor Cost* & Occupation & Labor Cost* \\
\hline Seaman & $47, .49$ month & $\begin{array}{c}\text { Unskilled labor } \\
\text { (fall) }\end{array}$ & $19.7,21.0$ days \\
\hline Farmer & $7.8,8.0$ days & $\begin{array}{c}\text { Unskilled labor } \\
\text { (summer) }\end{array}$ & $14.8,15.8$ days \\
\hline Skilled Craftsman & $5.7,5.8$ days & $\begin{array}{c}\text { Master } \\
\text { Tradesman }\end{array}$ & $9.2,9.8$ days \\
\hline $\begin{array}{l}\text { *Plymouth court fees in English Sterling (median, average): March 1740 (136.4 } \\
\text { pence, 140.3 pence); April 1783 (310.4 pence, 331.28 pence). } \\
\text { Source: See infra notes 55, 56, and 59 and accompanying text. }\end{array}$ \\
\hline
\end{tabular}

Relying on account books and probate records from scattered counties throughout Massachusetts, New Hampshire, and Connecticut, economic historian Gloria L. Main estimates that average daily wages in the period 1735 to 1754 were 24.0 pence Sterling for skilled craftsmen and 17.5 pence Sterling for farm laborers. ${ }^{55}$ Gary B. Nash reports that in 1740 Boston

54. There are no exactly comparable statistics on income or wages across these two periods. As in Table 1, all values have been converted to English Sterling, which was more stable than colonial money, to reduce the degree to which these comparisons would be distorted by inflation across the two periods.

55. See Gloria L. Main, Gender, Work, and Wages in Colonial New England, 51 WM. \& MARY Q. 39, 48 tbl.III (1994). The average daily wage for the period 1630 to 1774 was 18.3 pence Sterling for skilled craftsmen and 16.4 pence Sterling for farm laborers. See id. The average daily wage for women and girls was 7.3 pence Sterling and for boys (general labor) was 11.2 
seamen received $£ 1.2$ Sterling per month in wages.$^{56}$ Converted to English Sterling values,$^{57}$ the April 1740 court fees averaged 140.3 pence Sterling, with a median of 136.4 pence Sterling. According to these figures, then, to satisfy the average court fee in 1740 , a skilled craftsmen would have to work 5.7-5.8 days; and a farmer 7.8-8.0 days. Court fees alone for a typical uncontested debt suit in Plymouth County consumed 47\%-49\% of a Boston seaman's monthly income. These figures are conservative because, during a year of recession, such as 1740, wages (though not fees) dropped radically..$^{58}$ The drop in wages on account of the recession is not totally reflected in the wage data presented here.

Although the comparisons are not exact, the absolute level of court fees appears even higher in the period preceding Shays' Rebellion. Robert Taylor reports that, in 1781, Northampton paid master tradesmen 45 pence (33.74 pence Sterling) per day for summer labor and, in 1782, paid 28 pence (20.99 pence Sterling) and 21 pence ( 15.75 pence Sterling) per day for unskilled labor in the summer and fall, respectively. ${ }^{59}$ In 1783, the average and median Plymouth court fees were 331.28 pence and 310.4 pence, respectively. In the $1780 \mathrm{~s}$, then, for a master tradesmen, average court costs in an uncontested debt action consumed the income of 9.2-9.8 days; for unskilled labor, 14.8-15.8 days in the summer and 19.7-21.0 days - between two and three weeks of a six-day work week-in the fall.

Finally, as mentioned, the fees for proceeding before a justice of the peace were lower than for proceeding before the court of common pleas. They still were substantial, however, both as a percentage of the underlying debt and in absolute terms. To examine the differences, I relied on the records of a justice of the peace who practiced in Massachusetts during the period 1734 to $1761 .^{60}$ In a pool of eighteen cases from the period 1755 to

pence Sterling. See id. Main indexed prices to Sterling to account for both inflation and changing grain prices, since wages were sometimes paid in "country pay" - corn designated as commodity money. See id. at 46-47 n.24.

56. See Gary B. Nash, The Urban Crucible: Social Change, Political CONSCIOUSNESS, AND THE ORIGINS OF THE AMERICAN REVOLUTION 392-94 tbI.2 (1979). Nash reports the statistic in months; it is not evident how many days seamen worked per month.

57. I converted values in Massachusetts money to Sterling according to the exchange rate schedule in MCCUSKER, supra note 51, at 138-45 tbl.3.1.

58. For a discussion of the decline in wages during the recessions of the eighteenth century, see Joseph A. Ernst, "The Labourers Have Been the Greatest Sufferers": The Truck System in Early Eighteenth-Century Massachusetts, in MERCHANT CREDIT AND LABOUR STRATEGIES IN HistoRICAL PERSPECTIVE 16 (Rosemary E. Ommer ed., 1990).

59. See TAYLOR, supra note 4, at 195 n.56. According to Taylor, these wages are similar to those paid by other towns. See id. As discussed supra note 52, 1780s Sterling values were calculated according to the par exchange rate: $£ 133$ 7s. 6.d Massachusetts money equals $£ 100$ English Sterling.

60. See RECORDS OF THE COURT OF NATHANIEL HARRIS-ONE OF HIS MAJESTY'S JUSTICES OF THE PEACE WITHIN AND FOR THE COUNTY OF MIDDLESEX-HOLDEN AT WATERTOWN FROM 1734 TO 1761 (Watertown, Mass., Historical Soc'y of Watertown 1893). 
1761, the median fee represents $53 \%$ of the median debt. ${ }^{61}$ Again, relying on Gloria Main's wage estimates, ${ }^{62}$ the average and median fees consumed the income earned in 4.4-4.6 days of skilled labor and in 4.5-4.8 days of farm labor. The fees of justices of the peace, therefore, were lower than those of the court of common pleas, but remained extremely high in relation to the value of the debt involved and in absolute terms.

The findings here of high litigation costs raise substantial doubt about the debt-recording interpretation of colonial courts. First, it is not generally plausible that debtors would voluntarily consent to accept a burden in fees of up to $59 \%$ or $79 \%$ in small debt cases or from $16.9 \%$ to $21.7 \%$ at the median, in addition to the underlying debt, simply because of the efficiency of the debt collection process. Given these consequences, to voluntarily confess judgment or to allow judgment to enter by default is only likely to occur where something substantial is at stake and where the effort to collect a debt is real, not ministerial. Moreover, to characterize a system attended by costs of these magnitudes as "rationalized" and as a "recording device" ${ }^{63}$ seems misdescriptive. The costs attending resort to the colonial courts were substantial, both absolutely and in comparison to the underlying amounts in dispute. By contrast, the cost of perfecting a security interest in Massachusetts today is $\$ 10.00$, representing less than two hours labor at the minimum wage ${ }^{64}$ Far from the modest administration charges of a regularized bureaucracy, court fees in debt cases constituted a significant proportion of a colonial Massachusetts resident's weekly and even monthly wages.

\section{LitigATION Timing IN EIGHTEENTH-CENTURY MASSACHUSETTS}

It may be assumed that creditors in the colonial period were interested in maximizing the return on their investments, which is to say, obviously, repayment over nonpayment of their debts. The debt-recording interpretation of the colonial court system proposes that creditors maximized returns by gaining security through a debtors' confession of judgment or a default judgment immediately after extending the debt. Judgments provided creditors with the security that they could easily

61. All fees were converted to Sterling on the basis of McCusker's schedule, see supra note 51 , which allows precision by month.

62. See Main, supra note 55 , at 49 tbl.III.

63. See supra text accompanying notes 25,30 .

64. See Secretary of the Commonwealth of Massachusetts, Corporations Division, Uniform Commercial Code (UCC) Information (last modified Jan. 22, 1998) <http://www.magnet.state.ma.us/sec/cor/corucc/uccinf.htm\#ucc8>. Of course, the costs of enforcing a security interest and collecting on a debt are higher, but that is the point. 
liquidate the debt-by means of a simple execution procedure on the debtor's possessions - at any time desirable to the creditor. ${ }^{65}$

Part II suggested that the debt-recording interpretation of the courts is inconsistent with the high level of fees associated with colonial debt litigation. This Part examines the impact of those high fees on litigation timing. Section A analyzes the disincentives to litigation created by the fee structure. As I shall argue, although immediate litigation expedited the process of repossession and gave a creditor a lead over a debtor's other creditors, by burdening the debtor with court costs, it increased the likelihood of default. As a consequence, the determinants of litigation timing are much more complex than have been appreciated. Section B examines litigation timing in the Plymouth courts empirically.

\section{A. The Impact of the Colonial Fee Structure on Litigation Timing}

Colonial merchants and traders as well as farmers relied heavily on credit. ${ }^{66}$ By the 1730 s, credit was typically extended on promissory notes, ${ }^{67}$ bonds, ${ }^{68}$ and book accounts. At the purchase of goods, a merchant or trader typically gave the seller a note or a bond and repaid with goods or money (often both) at a later time. Different markets dictated different terms of credit. Secondary accounts claim that English merchants customarily sold goods to their colonial counterparts on twelve-month credit terms. ${ }^{69}$ In order to pay their English debts on time, New England merchants and traders offered goods locally on shorter credit terms. Though these estimates appear equally impressionistic, historians describe the customary

65. On colonial execution procedures, see, for example, 1 ACTS AND RESOLVES OF MASSACHUSETTS, supra note 37, at 372-75, ch. 4 (1700 Act describing procedures); 2 ACTS AND RESOLVES OF MASSACHUSETTS, supra note 37, at 838-39, ch. 19 (1737 Act specifying procedures); and id. at 1095, ch. 22 (1742 Act specifying procedures).

66. Virginia Harrington estimates that, prior to the Revolution, one-half to three-quarters of an average New York merchant's business transactions were on credit. See VIRGINIA D. HARRINGTON, THE NEW YORK MERCHANTS ON THE EVE OF THE REVOLUTION 103 (1935).

67. Promissory notes were signed written promises to perform a condition or pay a sum of money (like a check or IOU). See MANN, supra note 14, at 29. Notes were assignable and could circulate throughout a community as a currency. See Frederick K. Beutel, Colonial Sources of the Negotiable Instruments Law of the United States, 34 ILL. L. REV. Nw. U. 137, 141 (1939).

68. Conditional bonds were written sealed instruments by which debtors agreed to pay sums of money, which would become void if specific conditions were performed. See MANN, supra note 14, at 28-29; Zechariah Chafee, Jr., The Suffolk County Court and Its Jurisdiction, Introduction to RECORDS OF THE SUFFOLK COUNTY COURT, 1671-1680, 29 PUBLICATIONS COLONIAL SOC'Y MASS. at xxxviii-xl (1933).

69. See HARRINGTON, supra note 66 , at 101; 1 KENNETH WIGGINS PORTER, THE JACKSONS AND THE LEES: TWO GENERATIONS OF MASSACHUSETTS MERCHANTS, 1765-1844, at 14, 478 (1937); JAmes F. SHEPARd \& Gary M. WAlton, Shipping, Maritime Trade, and THE ECONOMIC DEVELOPMENT OF COLONIAL NORTH AMERICA 131 (1972). Dutch merchants generally required payment in 3 months. See HARRINGTON, supra note 66, at 101. Substantial premiums were given for cash purchases. See id. at 102-03. 
terms of credit extended to local retailers as ranging from six to twelve months, and possibly less. ${ }^{70}$ No matter what the credit terms, however, due dates were not typically specified. Most frequently, creditors opted to retain discretion over legal due dates by specifying that the debt was due "on demand." 71 This gave them the option, if they so chose, to sue immediately after extending the debt.

Assuming that a creditor's monetary needs remained constant throughout the period of outstanding debt, the colonial fee-structure created a disincentive to litigate immediately to record a debt through a default judgment against the debtor. As mentioned, when creditors went through the legal process to obtain default judgments, they imposed substantial costs on debtors: The debtor had to pay both the debt and court costs. ${ }^{72}$ The effect of imposing these costs on debtors was similar to increasing the magnitude of debt in a given agreement or, when expressed as above as a percentage of debt, similar to increasing the interest rate. As described above, the Plymouth data reveal that average court costs represented $32.6 \%$ and $25.5 \%$, respectively, of the median 1740 and 1783 debt amounts in cases ending in default, and for lower amounts as much as $79 \%$ or even more. ${ }^{73}$ Thus, assuming a full twelve-month loan, litigation was equivalent to increasing the interest rate on those debts by $32.6 \%, 25.5 \%$, or even $79 \%$.

While increasing the magnitude of debt is obviously harmful to debtors, it is not clearly equally beneficial to creditors. Increasing the debt burden directly increases the chance of debtor default. ${ }^{74}$ Imposing court costs on the debtor reduces what is available as repayment to the creditor. The fees themselves went to judicial officials; the creditor gained only priority and ease of execution. In addition, increasing the magnitude of debt changes debtors' incentives. When the interest rate or debt burden rises, the chance that debtors will be able to profit from low-risk investments declines, and debtors willing to borrow at that rate are more likely to invest in high-risk investments, leading to greater rates of default. ${ }^{75}$ Thus, given the high costs and fees attending colonial litigation, imposing court costs on debtors

70. See HARRINGTON, supra note 66, at 101 (suggesting between 3 and 12 months as the customary terms for domestic credit); JAMES H. SOLTOW, THE ECONOMIC ROLE OF WILLIAMSBURG 133 (1965) (describing customary domestic credit terms as between 6 and 12 months).

71. When due dates were specified, it was typically to set a date at which interest would begin accruing. See, e.g., Letter from Bourryau \& Schaffer to Thomas Hancock (Feb. 6, 1743), reprinted in W.T. BAXTER, HOUSE OF HANCOCK: BUSINESS IN BOSTON, 1724-1775, at 219 (1945) (allowing Hancock 6 months credit and requesting 5\% interest thereafter); HARRINGTON, supra note 66, at 102 (describing both credit agreements in which interest began accruing immediately, and after 6 months).

72. See supra text accompanying note 40 .

73. See supra Table 1 \& note 53.

74. See, e.g., Joseph E. Stiglitz, The Causes and Consequences of the Dependence of Quality on Price, 25 J. ECON. LIT. 1, 6-7 (1987).

75. See id. 
increased the chance of default with no direct monetary benefit to creditors. It is, therefore, not obvious that debt litigation would be brought principally for recording or bureaucratic reasons, as opposed to a real economic desire to collect the debt.

There may be separate reasons, of course, for creditors to sue immediately or shortly after extending debts. Creditors might litigate immediately when, for example, they gain new and adverse information about debtors' liquidity unknown when the credit was extended. Similarly, a creditor might desire an immediate default judgment upon the fear that the debtor will be sued by other creditors. Any money or goods that other creditors obtained from the assets of a financially troubled or insolvent debtor would decrease the assets available to all other creditors. Finally, creditors might sue immediately if they themselves suffer unexpected economic reverses compelling a greater demand for their own liquidity.

In most county court cases, however, immediate litigation was not likely to be desirable under the colonial fee structure. Rather than propel default by imposing the burden of court costs on the debtor, creditors were likely to wait to litigate until obtaining a credible signal that a debtor's investments were not resulting in profitable returns, or that the debtor was about to be sued by other creditors. Thus, in an environment where creditors customarily extended credit on a six to twelve month basis, it is likely that creditors would typically initiate lawsuits only after six to twelve months, when they learned that they would not be voluntarily repaid.

As mentioned, justices of the peace resolved disputes involving less than forty shillings and charged less for their services. Lower fees reduced the disincentive to litigate. It is likely, therefore, that creditors obtained default judgments against debtors more quickly when the debt fell within the jurisdictional amount of the justices of the peace.

The hypothesis that creditors were reluctant to bring debt litigation in the absence of an actual or potential default is confirmed by contemporary accounts. Virginia Harrington's examination of New York merchants' business records reveals, for example, that businessmen were extremely reluctant to sue and that inquiries concerning a debtor's solvency were kept very quiet so that other creditors would not litigate first. ${ }^{76}$ Merchants usually went to great lengths to find solutions to avoid litigation. ${ }^{77}$ James Soltow's study of Virginia merchants suggests that, before litigating, creditors tried to gain security through an alternative use of conditioned bonds. When a debtor failed to pay a debt on time, a creditor might require

76. See HARRINGTON, supra note 66 , at 119.

77. See id. at 120-21 (describing the emergence of a "foreign attachment" system, the "essence of [which] is the ability of the creditor to attach the property of the alleged debtor, wherever it could be found, without formal judgment in court"). 
the debtor (under threat of litigation) to enter a bond agreement, attaching real estate or property as collateral and requiring the signatures of guarantors. ${ }^{78}$ Litigation, according to Soltow, was "a last resort." 79 W.T. Baxter's review of the debt collection practices of the Hancock family in Massachusetts led him to conclude similarly that "[a]most every account tells the same long-drawn-out story of dawdle and delay." ${ }^{80}$ These accounts, of course, are anecdotal, and have yet to be empirically examined.

\section{B. Empirical Evidence on Litigation Timing in Plymouth}

As mentioned, the debt-recording interpretation of colonial courts has not been supported by direct empirical study of litigation timing but, rather, is merely an interpretation of the discovery of the high percentage of default judgments in debt cases beginning in the 1720s and 1730s ${ }^{81}$ This Section looks at the question directly. It examines 5048 cases in the Plymouth Court of Common Pleas over two periods: 1724 to $1750^{82}$ and 1781 to 1786 . The first half of the eighteenth century has been the focus of the debt-recording school. ${ }^{83}$ The period 1781 to 1786 marks the time from the courts' reopening after the Revolution until Shays' Rebellion.

The Section precisely measures the number of days between the date the debtor signed the note or sealed the bond and the date the creditor filed suit against the debtor in court. ${ }^{84}$ The Plymouth County court records provide a signing or sealing date for almost every note and bond, as well as an exact court filing date. This study principally focuses on default judgments-the central focus of the debt-recording interpretationalthough it also examines the timing of litigation in those cases where

78. See SOLTOW, supra note 70 , at $140-42$; Rosen, supra note 28 , at 233 ; see also MANN, supra note 14 , at $103,112-15$ (describing the use of penal bonds to secure arbitration awards).

79. SOLTOW, supra note 70 , at 142.

80. BAXTER, supra note 71 , at 192 .

81. See supra text accompanying notes $22-25$.

82. Data from 1718 are also included in the average and median calculations. There were too few cases during the period 1719 to 1723 to merit inclusion.

83. See supra text accompanying notes 19-35.

84. This Note's empirical sections rely on a subsection of cases found in the records of the Plymouth Court of Common Pleas. The data set includes all cases brought on promissory notes, bonds, or other written credit instruments where a date of agreement was included (a small minority with no recorded date or with incomplete dates, e.g., no month or day were excluded). Although book accounts were a widely-used form of debt instrument, the records do not include dates of agreement for book account cases, so I excluded these cases from the study. I also excluded litigation on all government matters, such as cases brought by the Town Loan commissioners, for fear that the timing of these lawsuits was determined by political processes rather than by more typical economic forces. Also important, the date of litigation always refers to the date the case originally was filed. No cases continued from a prior term were included. To generate values on the timing of litigation, I entered the data on a spreadsheet that can calculate among all days since 1600 , accounting for variations by months and in leap years. 
defendants appeared in court and confessed judgment against themselves (only thirty-four of the entire sample). ${ }^{85}$

Subsection 1 presents the data on the number of cases filed immediately or soon after execution of the debt. Subsection 2 presents data describing the timing of debt litigation in Plymouth in cases ending in defaults and confession of judgment more broadly. Subsection 3 examines the timing of litigation in a justice of the peace court.

\section{Empirical Support for the Debt-Recording Interpretation of Colonial Courts}

The debt-recording interpretation implies that creditors sought default judgments against debtors immediately or soon after extending the debt. Thomas Russell, building on the interpretation, suggests that, as early as the eighteenth century, creditors may have obtained default judgments against debtors on the same day that the debt was extended. ${ }^{86}$ But the debtrecording hypothesis need not be defined this strictly. First, county court sessions met quarterly; thus, cases brought within the first quarter following execution of the debt may still confirm the hypothesis. ${ }^{87}$ Second, although not described in any of the literature, I have discovered a number of cases in which the date the debt was allegedly signed occurred after the date the suit was filed in court, which is to say, that the note or bond was post-dated for purposes of the litigation. Though somewhat peculiar, these cases certainly seem to support the proposition that creditors and debtors colluded in debt litigation for purposes of facilitating debt collection.

The evidence from Plymouth County, however, does not generally support the debt-recording interpretation. First, aggregating cases filed on or prior to the reported date of execution (a very small number) along with cases filed within the first quarter following execution, during the period 1724 to 1750 , only $4.6 \%$ (163 of 3517) of all uncontested debt cases were litigated at the first court date available. During the period 1781 to 1786 , a slightly higher percentage, 6.1\% (94 of 1531), were litigated at the first possible court session. These figures may provide support for the proposition that some creditors did, in fact, use the colonial courts for recording purposes, although they may reflect collection on short-term debt.

85. I kept separate records of default and non-default cases. For the period 1718 and 1724 to 1750 , there were 3517 cases with default judgments; and 452 cases without them. From 1781 to 1786, there were 1531 cases with default judgments; and 45 cases without them. Non-default judgment cases include cases that were contested leading to a jury trial; cases where parties referred the matter to arbitrators; and nonsuit determinations, where plaintiffs failed to appear.

86. See Russell, supra note 31 , at 362-63.

87. For this purpose, I have indicated cases filed within 92 days of execution of the debt. 
Cases brought before the alleged execution date represent less than one percent of all cases. For the period 1724 to 1750, of 3517 uncontested cases, only ten were brought before the alleged signing date. In the period 1781 to 1786 , of 1531 uncontested cases, eight were brought before the signing date. These numbers are too low to conclude that creditors and debtors often agreed to post-date bonds and notes to allow creditors to sue. They do reveal, however, that post-dating credit instruments was a legally available avenue that was not used in the vast majority of cases.

Perhaps the debt-recording interpretation should be further relaxed by considering cases brought within two court sessions of debt execution (six months), rather than one. Common pleas courts met only in one town in each county, ${ }^{88}$ and it may have been hard for creditors to appear at the first possible session. In addition, the Plymouth Records reveal that more cases were brought during the winter than during the summer harvest months, suggesting that creditors may have been reluctant or unable to go to court during the harvest season. ${ }^{89}$ An extension of this nature is problematic, however, even according to the debt-recording view, since extending the period of time prior to recording the debt multiplies the likelihood that the debtor will obtain additional credit and that those or preexisting creditors may record their debts earlier. Of course, an extension to six months also confounds the identification of recording with legitimate efforts to collect three- or six-month debt obligations.

Even if one considers a broader period, the data do not provide strong support for the debt-recording interpretation. In the period 1724 to 1750 , an additional 9.6\% (339 of 3517) of cases were brought between three and six months of debt execution. In the period 1781 to $1786,11.2 \%$ (171 of 1531) were brought between three and six months. At best, then, ignoring the possibility that these cases (or some substantial portion of them) represent legitimate efforts to collect short-term debt, the debt-recording interpretation of colonial courts explains no more than 5\% to $7 \%$ of all debt cases, including those brought within three months, and $15 \%$ to $18 \%$ of all cases, including those brought within six months. ${ }^{90}$

88. In Plymouth County, the common pleas court sat quarterly in the town of Plymouth. See NELSON, supra note 13, at 23.

89. Of course, it is also possible that creditors typically litigated in the winter because most farmers' debts were due after the harvest, making the winter the appropriate time to file suit against defaulting debtors.

90. Thomas Russell estimates that concomitant litigation and lending occurred in $34.9 \%$ of cases in South Carolina in the period from 1820 to 1840 . See Russell, supra note 31, at 352. Certainly, this difference of $20 \%$ to $30 \%$ between the 18th and 19th centuries suggests substantial differences between the colonial and 19th century legal environments. Russell's estimate may misrepresent the extent of concomitant litigation and lending, however, because he assumes that all cases in which defendants confessed judgment occurred on the day that their debts were extended. 
2. The Timing of Litigation and the Function of the Colonial Courts

\section{a. Cases Ending in Default Judgments}

Table 3 departs from the debt-recording interpretation and describes litigation timing more broadly. It shows the proportion of all debt cases resulting in default judgments filed at various intervals following execution of the debt. As can be seen in the Table, there is a wide distribution with respect to the period between execution and litigation to collect both in the 1724 to 1750 and 1781 to 1786 periods. As described above, $14.5 \%$ and $17.9 \%$ of cases were litigated within six months of execution in the periods 1724 to 1750 and 1781 to 1786 , respectively. A substantially greater proportion, $21.4 \%$ and $22.9 \%$, respectively, were litigated within the succeeding six months. The Table shows, in fact, that roughly half of all cases were litigated between six months and two years after execution ( $48.8 \%$ and $48.7 \%$, respectively), and $60 \%$ between six months to three years $(62.9 \%$ and $57.8 \%$, respectively). The median period between debt execution and suit for all cases is 17.5 months during the period 1724 to 1750 , and 14.0 months during 1781 to 1786.

\section{TABle 3: The Timing of Litigation in Debt CASES Resulting IN DEFAULT: 1724 TO 1750, 1781 TO 1786}

\begin{tabular}{|c|c|c|}
\hline $\begin{array}{c}\text { Period following } \\
\text { Execution }\end{array}$ & $\begin{array}{c}1724 \text { to } 1750 \\
(3,517 \text { cases })\end{array}$ & $\begin{array}{c}1781 \text { to } 1786 \\
(1,531 \text { cases })\end{array}$ \\
\hline$<3$ months & $4.9 \%$ & $6.7 \%$ \\
\hline 3 to 6 months & $9.6 \%$ & $11.2 \%$ \\
\hline Total 6 Months or Less & $\mathbf{1 4 . 5 \%}$ & $\mathbf{1 7 . 9 \%}$ \\
\hline 6 to 12 months & $21.4 \%$ & $22.9 \%$ \\
\hline 1 to 2 years & $27.4 \%$ & $25.8 \%$ \\
\hline 2 to 3 years & $14.1 \%$ & $9.1 \%$ \\
\hline $\begin{array}{c}\text { Total 6 Months to 3 } \\
\text { Years }\end{array}$ & $\mathbf{6 2 . 9 \%}$ & $\mathbf{5 7 . 8 \%}$ \\
\hline 3 to 5 years & $11.7 \%$ & $7.1 \%$ \\
\hline 5 to 10 years & $8.0 \%$ & $9.4 \%$ \\
\hline$>10$ years & $2.9 \%$ & $7.8 \%$ \\
\hline Total Over 3 Years & $\mathbf{2 2 . 6 \%}$ & $\mathbf{2 4 . 3 \%}$ \\
\hline \multicolumn{2}{|c|}{ Median Interval } \\
Execution to Suit & 531.5 days & 427 days \\
\hline Source: 5-7, 9-10 PLYMOUTH COURT RECORDS, supra note 16. \\
\hline
\end{tabular}


These figures suggest that debt litigation in the colonial courts represents a genuine effort to collect debt, rather than mere debt recording. As discussed above, historians report that debts in the colonies were customarily extended on a six- to twelve-month basis. If so, most litigation occurred within a short time (within two or three court sessions) after the debtor failed to pay when due. Data on the exact terms of underlying colonial credit is unavailable. ${ }^{11}$ The $21.4 \%$ and $22.9 \%$ of cases in Table 3 litigated within six to twelve months of execution, however, are likely to represent debts extended on shorter credit terms. Similarly, the $27.4 \%$ and $25.8 \%$ of cases in Table 3 litigated within one to two years of execution are likely to represent suits to collect on debts extended on a twelve-month basis.

Some credit agreements did specify explicitly a date on which the debt was due. The timing of cases based on these credit instruments supports the proposition that creditors litigated within six to nine months of default. In the periods 1724 to 1750 and 1781 to 1786 , respectively, 362 cases (of 3517 ) and 330 cases (of 1531) were brought involving credit instruments providing a specific due date. Although not indicated in Table 3, for these cases, the median interval between the specified due date and litigation was 212 days, or 6.99 months for the period 1724 to 1750 , and 254 days, or 8.35 months, for the period 1781 to 1786 . These figures serve as a good proxy for the timing of cases even when a due date was not specified: Creditors litigated within two to three court sessions after debtors' defaults.

What about the cases indicated in Table 3 that remained outstanding for over three years? Debts litigated after three years can be explained in several ways. First, in many cases, delayed litigation related to the nature of the credit instruments involved. As described above, bonds were at times used to extend credit on a more secured basis to defaulting debtors. ${ }^{92}$ Second, in some cases, creditors agreed to postpone debt litigation in order to increase the ultimate chances of collecting the debt. As mentioned, historians have found extensive evidence that creditors tried to find ways to collect without litigation, such as with deferred payment plans, postponing litigation as long as possible. ${ }^{93}$ Third, in the colonial period, debt

91. For references to existing work by historians examining colonial merchants' records, see supra notes 69-71 and accompanying text. None provides a good estimate of credit terms within the colonial economy overall.

92. See supra text accompanying note 78 . It is unclear from the court records, however, what percentage of bond cases correspond to this arrangement. During the period 1724 to $1750,60 \%$ of all uncontested cases involved bonds and $37 \%$ involved notes. After the Revolution, notes dominated the dockets ( $96 \%$ of all cases concerned notes).

93. See supra text accompanying notes 76-79. Indeed, the high costs of colonial litigation, even if levied entirely against the debtor, encouraged this approach. These accounts suggest why some debts may have remained outstanding for several years, although the Plymouth evidence, to a great extent, suggests that historians have overstated the extent to which merchants deferred 
obligations represented a principal form of savings, which may have led colonists to hold on to bonds and notes for long periods of time. ${ }^{94}$

\section{b. Cases Ending in Confessions of Judgment}

According to the debt-recording interpretation of colonial litigation, cases in which defendants confessed judgment against themselves represent litigation for the purpose of recording and securing debts perhaps even more clearly than cases ending in default judgments. ${ }^{95}$ The fact that debtors confessed judgment in court suggests that these cases were brought with debtors' consent, purely to give the creditor greater security; presumably, otherwise the debtor would have paid the debt. Table 4 presents data on the median interval of time between debt execution and litigation in cases where debtors confessed judgment. Table 4 suggests that the debt-recording interpretation of confession of judgment cases in the county courts is not fully explanatory.

\section{TABLE 4: THE TIMING OF LITIGATION IN CONFESSION OF JUdGMENT CASES}

\begin{tabular}{|l|l|l|}
\hline & $\begin{array}{l}1724-1750 \\
(30 \text { cases })\end{array}$ & $\begin{array}{l}1781-1786 \\
(4 \text { cases })\end{array}$ \\
\hline $\begin{array}{l}\text { Median Interval } \\
\text { Agreement Date to Suit: }\end{array}$ & $\begin{array}{l}1549.5 \text { days } \\
48.0 \text { months }\end{array}$ & $\begin{array}{l}390.5 \text { days } \\
12.8 \text { months }\end{array}$ \\
\hline Source: 5-7, 9-10 PLYMOUTH COURT RECORDS, supra note 16. \\
\hline
\end{tabular}

As is shown in Table 4, in the median confession of judgment case during the period 1724 to 1750 , the time between debt execution and litigation was approximately four years, as compared to 17.5 months in the median default judgment case during the same period, as is shown in Table 3. During the period 1781 to 1786 , in the median of the four cases where defendants confessed judgment, the period of time between debt execution and litigation was 12.8 months, closely similar to the median default case, litigated 14.0 months after execution. Clearly, in Massachusetts before the Confession Act, ${ }^{96}$ confession of judgment cases cannot be characterized as

litigation. Table 3 shows that $77.4 \%$ and $75.7 \%$ of all debt cases, respectively, were litigated within three years of the extension of the debt.

94. See Alice Hanson Jones, Wealth of a Nation To Be: The American Colonies on THE EVE OF THE REVOLUTION 127-34 (photo. reprint 1997) (1980) (discussing the importance of outstanding debt obligations to the assessment of colonists' net worth).

95. See MANN, supra note 14, at 40; Rosen, supra note 28, at 234.

96. As we shall see in Section IV.D, the Confession Act of 1786 required all debtors to confess judgment to record debts at the outset of litigation. Thus, in some contexts, confession of judgment cases may signal an effort to record and secure debts. 
special cases in which debtors consented to be sued for the purpose of recordation. Debtors confessed judgment in cases where creditors had waited to litigate as long, or longer, than in cases where debtors defaulted.

\section{The Timing of Litigation in the Justices' Courts}

Finally, the timing of litigation in cases before a justice of the peace was radically different. Harris's records reveal that, for the eighteen cases he decided, the median period between debt execution and suit was 150.5 days (5.0 months) and the average period, 215.7 days ( 7.1 months) ${ }^{97}$ Table 3 shows in comparison that the median period between execution and suit in the court of common pleas was 531.5 days (17.5 months). There are good reasons for these differences. Justices' fees were lower, though not insubstantial,${ }^{98}$ reducing the disincentives toward early suit. In addition to lower fees, justices typically resided in the same town as the litigants; creditors, therefore, were not as restricted in choosing when to sue as before the quarterly common pleas sessions. Third, justices of the peace decided cases involving small sums of money. If debts for small sums were typically extended on shorter credit terms, then this would also explain why cases were brought earlier in the justices' courts.

Along with the fee data presented in Part II, the litigation timing data displayed here show that colonial debt litigation was motivated principally by the real economic ambition of collecting debt. The debt-recording interpretation is not generally available for the large majority of debt cases. The high costs of debt litigation complicated a creditor's collection strategies, principally by creating a strong incentive to delay litigation.

Based upon this understanding of the operation of colonial debt litigation, Part IV examines more carefully the grounds of Shays' Rebellion and the effects of the reforms introduced in response. As we shall see, external economic forces might increase liquidity pressures, both increasing the extent of default and increasing creditors' demand for repayment sufficient to justify the high costs of litigation. Earlier historical accounts well recognize that Shays' Rebellion represented an attack on the courts, motivated by concerns about debt litigation and high court costs. The underlying basis for the Rebellion in terms of the conduct of debt litigation, however, has not been fully explored. Part IV reviews the historical accounts of the Rebellion and then examines litigation data to provide a deeper understanding of the crisis.

97. Note that the sample size here is very small (18 cases) because of the infrequency with which Harris recorded a signing or sealing date.

98. See supra text accompanying note 61 . 


\section{SHAYS' REBELLION: LITIGATION TRENDS DURING RECESSION AND THE IMPACT OF COURT REFORM}

In 1786 and 1787, the Regulators engaged in violent protests throughout New England, closing the common pleas courts in seven Massachusetts counties and temporarily suspending debt-collection..$^{99}$ By the end of 1786, the insurgents numbered $9000,{ }^{100}$ and the Federalists viewed the rebellion as posing a threat to constitutionalism and democracy. ${ }^{101}$ Shays' Rebellion arose out of an economic climate of severe recession and extreme monetary deflation, but it was propelled by what the Regulators perceived to be an inadequate legislative response to the burdens imposed on the citizenry, particularly with respect to those owing private debts. Although violence was focused in the years 1786 and 1787, understanding Shays' Rebellion requires an examination of the postwar economic problems, the legislative responses that Regulators perceived as inadequate, and the effect of economic conditions and remedial legislation on litigation trends. Section A examines the economic conditions that motivated mass protest in Massachusetts. Section B describes legislative responses to the Regulators' demands. Section $C$ analyzes how litigation volume and the timing of litigation transform during periods of deflation and recession and surveys trends in litigation in Plymouth, Massachusetts between 1781 and 1786. Finally, Section D examines the adoption of a debt-recording regime in response to the Rebellion.

\section{A. Economic Conditions in Massachusetts, 1781 to 1790}

There were three principal contributing factors to the depression of the 1780s: economic stagnation, heavy taxes, and the removal of Continental bills, which caused a return to reliance on gold and silver coins as currency. ${ }^{102}$ The effects of economic recession were felt as early as 1780 when the center of wartime activity shifted to the South. The closure of trade with the West Indies deprived New England of its principal outlet for

99. See SZATMARY, supra note 4, at 58-59. The Regulators closed courts in Northampton, Worcester, Concord, Great Barrington, Springfield, and Berkshire counties, and Taunton in Bristol County. See id.

100. See id. at 59.

101. See JACKSON TURNER MAIN, THE ANTI-FEDERALISTS: CRitics OF THE Constitution, 1781-1788, at 59-64 (1974); JACK N. RAKOVE, ORIGINAL MEANINGS: POLITICS AND IDEAS IN THE MAKING OF THE CONSTITUTION 33-34 (1996); GORDON S. WOOD, THE CREATION OF THE AMERICAN REPUBLIC, 1776-1787, at 325-28 (1998).

102. The factors contributing to the post-American Revolution recession are widely discussed in historical scholarship. See, for example, MCCUSKER \& MENARD, supra note 34, at 367-77, for a more detailed description of economic conditions after the Revolution. For a discussion of problems generated by currency and the need to pay federal and state debts in the aftermath of the war, see FERGUSON, supra note 52, at 179-219. 
agricultural and timber exports. ${ }^{103}$ New England's shipping and fishing industries became almost entirely stagnant and were not revived to former levels until long after the War. ${ }^{104}$

Severe recession began in 1779 and 1780, when state governments actively pursued plans to remedy the crisis conditions relating to their wartime debts. The first priority was to bring an end to the hyperinflation plaguing state economies. States had resorted to financing their operations through the voluminous issuance of paper money. The money had little backing and, beginning in 1776, the value of bills rapidly depreciated while prices skyrocketed. ${ }^{105}$ In 1780 , Massachusetts suddenly extinguished the paper money by repealing the 1776 Tender Act, which had made the Continentals legal tender for the purposes of private and public debts. ${ }^{106}$ The Continentals depreciated to insignificant values, forcing an immediate return to a hard money system, and requiring debtors to pay creditors the nominal value of their debts in specie. ${ }^{107}$ Thus, for the first time since 1775, debtors were required to pay debts in gold and silver coins, rather than in money that had rapidly lost value.

Pressed by a sense that a return to political normalcy required extinguishing public debt, the Massachusetts General Court imposed taxes totaling $£ 17,878,706$ in 1780 , initiating a period of extreme recession. ${ }^{108}$ Massachusetts adopted a uniquely strict reimbursement policy that historians have viewed as a windfall to public creditors. ${ }^{109}$ The General Court paid its debts in specie amounts corresponding to the value of the debt before depreciation. Creditors who had lent the government Continentals during the war, for example, were paid back an amount corresponding to the value of those bills at the time they were issued, rather than at the time of the debt. Moreover, Massachusetts paid interest on these debts in specie. ${ }^{110}$

The economic recession worsened in the period 1781 to 1784 . In 1781, the General Court levied an extremely unpopular excise tax on wines, liquors, tea, coaches and other luxury items. ${ }^{111}$ The General Court imposed $£ 200,000$ in general taxes in both 1782 and 1783 , and $£ 140,000$ in 1784 , and the accumulated effect of four years of heavy tax burdens quickly drove

103. See MCCUSKER \& MENARD, supra note 34, at 370.

104. See TAYLOR, supra note 4 , at $103-04$.

105. See FERGUSON, supra note 52, at 59; Charles W. Calomiris, Institutional Failure, Monetary Scarcity, and the Depreciation of the Continental, 48 J. ECON. HIST. 47 (1988).

106. See TAYLOR, supra note 4 , at 106.

107. See id. at 105-07.

108. See id. at $108,122,132$.

109. See, e.g., FERGUSON, supra note 52, at 245 (describing the Massachusetts public debt payment plan as "arbitrary" and as "conferring unmerited gains upon individuals").

110. See id.

111. See TAYLOR, supra note 4, at 109. 
many to the brink of insolvency. In response to mass protest, no general property taxes were levied in 1785 , although the Court levied a special tax on court services, which raised the fees of judges, justices of the peace, and other officers of the court. ${ }^{112}$ In 1786, the General Court responded to pressure exerted by unpaid Revolutionary soldiers by imposing a tax of $£ 300,000$, in part to pay the soldiers' past wages. ${ }^{113}$

The impact of the return to the hard-money system, heavy taxes beginning in 1779, a federal impost tax first imposed in 1782, ${ }^{114}$ and the stagnation of trade resulting from British and Spanish exclusion, led to an overall economic climate of recession and stagnation. McCusker and Menard estimate that the performance of the British American economy declined $46 \%$ in the period 1775 to 1790 . The postwar recession, thus, rivals the Great Depression, where the per capita gross national product declined 48\%. ${ }^{115}$ Shays' Rebellion began in August 1786, propelled by the long-run effect of recession and by the harsh responses to the demands for legislation that would alleviate the burden of recession on debtors.

\section{B. Remedial Legislation Preceding Shays' Rebellion}

Heavy taxes and the repeal of the Tender Act in 1780 propelled an organized mass protest movement throughout Massachusetts achieving its greatest intensity in the famous court closings of 1786 and $1787 .{ }^{116}$ Debtors had become accustomed to an economic climate of easy access to paper money. ${ }^{117}$ After the repeal of the Tender Act, organizers held conventions throughout Massachusetts, particularly in the west where currency was most scarce, calling for the issuance of a new government paper money to ease credit conditions. ${ }^{118}$ These efforts were rebuffed entirely. The government continued its tax collection activities, refused all demands for a paper money and, as mentioned, in 1781, imposed an additional excise tax on luxury goods.

112. See 1784-1785 Mass. Acts 458-62, ch. 18.

113. See TAYLOR, supra note 4 , at 132 .

114. See FERGUSON, supra note 52, at 152.

115. See MCCUSKER \& MENARD, supra note 34 , at $373-74$ (noting that this estimate may be revised with further research).

116. This account relies heavily on Robert J. Taylor's Western Massachusetts in the Revolution, which provides the most detailed account of protest activities in years preceding Shays' Rebellion. See also NELSON, supra note 21, at 69-72 (discussing the agrarian court reform movement of 1780 to 1786 ).

117. Of course, depreciating money permitted debtors to repay creditors less in real terms than what they had borrowed. Those debtors who wanted to maintain continuing relations with creditors may not have taken advantage of the opportunity to pay the nominal, rather than the real, value of the debt. See TAYLOR, supra note 4, at 105. Nonetheless, immediate cancellation of paper money and reversion to use of gold and silver was likely to make credit more costly and incur hardship on both creditors and debtors.

118. See id. at 107. 
After the failure of the paper money initiatives, organized protesters challenged the costliness and inefficiency of the common pleas courts. ${ }^{119}$ Their principal concern was that court fees were unjustly high and represented abuse by government officials and lawyers whose income was based on fees. ${ }^{120}$ The protesters also claimed that officials and lawyers routinely over-charged litigants for attendance and transportation. ${ }^{121}$ The judicial system seemed entirely structured around the interests of those profiting from it-judges and lawyers-rather than the creditors who relied on the courts for collection or the debtors compelled by process to pay the fees.

In the period preceding Shays' Rebellion, however, the General Court rejected these reform demands as well and passed remedial acts of only minor import. In 1782 the General Court empowered justices of the peace to record debtors' confessions of judgment for a reduced fee (thirty pence). ${ }^{122}$ This statute marks the first important attempt to use the justices of the peace to serve a recording function. These fees were remarkably low for the time, representing approximately one day's farm labor in rural Massachusetts. ${ }^{123}$ Moreover, the statute only required creditors to execute on the debtors' goods within three years, which suggests that the purpose of the statute was to encourage creditors to record and secure their debts well in advance of execution. ${ }^{124}$ The impact of the statute was limited, however, because it did not expand the jurisdiction of the justices of the peace, then limited to cases involving less than $£ 2 .{ }^{125}$

In 1784, in response to the statewide protests against the common pleas courts, the General Court enacted a second statute advancing the judicial system further towards a recording function by expanding the jurisdiction of justices of the peace to matters up to $£ 4 .{ }^{126}$ This act was likely to have had a substantial impact on debt litigation, because it provided a less

119. The issue of court fees naturally followed from the rejection of the proposal for the issuance of paper money because cheaper money would have remedied the protestors' complaints. Inflation lowered the real, as opposed to nominal, value of court fees as well as debts. When the value of money was increased substantially (deflation), the costs of litigation were felt more severely. As discussed infra Section IV.C, another problem of the time was that under conditions of severe recession, high court fees did not deter litigation. Litigation volume grew despite the increase in the real value of the fees.

120. See TAYLOR, supra note 4, at 113.

121. See id. at 115.

122. See 1782-1783 Mass. Acts 53-59, ch. 21.

123. See supra text accompanying note 59 .

124. See 1782-1783 Mass. Acts 55, ch. 21.

125. A second remedial act in 1782 was the Pine Board Act, which for one year enumerated cattle, sheep, swine, flour and other goods as tender for the purpose of private debts. See id. at 31, ch. 10. The effect of the Pine Board Act was limited as well, and it may have influenced creditors to wait to litigate until 1783 , when debts would again have to be paid in specie or its equivalent. See TAYLOR, supra note 4, at 117.

126. See 1782-1783 Mass. Acts 605-09, ch. 42. 
expensive process for smaller debts. For all cases involving debts greater than $£ 4$, however, the court system remained unchanged.

Thus, before the court closings beginning in 1786, the Massachusetts legislature made only token efforts to address the problems at the forefront of the protest. Section C examines the basis for the Rebellion more carefully by analyzing how recession conditions affected the decision to litigate over debt, and by reviewing the actual litigation data from Plymouth County before and after the Rebellion.

\section{Changes in Litigation Preceding Shays' Rebellion}

Shays' Rebellion was a reaction to the high costs of credit and court fees in an environment of deflation and recession. In conditions of deflation, the value of currency appreciates. Obligations increased in value in real terms as a result of deflation in Massachusetts between 1780 and 1786, because both court fees and existing debts were set in nominal amounts. As described earlier, in stable economic conditions, high court fees would lower total litigation volume. Under conditions of severe recession and deflation, however, creditors' incentives often changed.

During periods of recession, more businesses fail, consumer demand drops, and unemployment increases. Each of these economic forces is likely to increase litigation over debts. Tight money, or greater demand for liquidity, typically a feature of recessions, can in itself have widespread implications for litigation rates, especially in contexts of an interwoven fabric of credit and debt among merchants, traders, farmers, and others. If faced with litigation, a creditor is more likely to begin proceedings against her own debtors, to gather assets to ward off foreclosure. These demands, in turn, pressure debtors to call in debts from their debtors, who are forced to do the same. ${ }^{127}$

Widespread business failure also means that more investments will unexpectedly prove unprofitable, requiring litigation in cases in which it would otherwise not be necessary. Recessions generate greater uncertainty, not only as to which businesses are doing well and which are not, but also as to which debtors are the subject of lawsuits that may allow other creditors to gain priority. ${ }^{128}$ Litigation does not follow necessarily. High litigation fees and their depletion of available assets create incentives to reach out-of-court settlements. But the existence of competing creditors complicates the decision. Each of these factors affected the litigation

127. See Rosen, supra note 14 , at 146.

128. In the 18th century, there was no system like the current bankruptcy Chapter 11 regulations to rationalize the process of distribution of the creditor's assets. Thus, creditors had a strong incentive to be the first to secure a writ of execution to force an auction of the debtor's possessions. 
environment in Massachusetts preceding Shays' Rebellion. ${ }^{129}$ Moreover, the escalating protest efforts regarding economic hardship may also, ironically, have encouraged debt litigation, because creditors sued out of fear that the legislature might institute inflationary paper-money policies to bring an end to the state's political troubles. ${ }^{130}$

Although it is widely known that Shays' Rebellion was precipitated by an increase in debt litigation, few works have empirically examined litigation trends before Shays' Rebellion to appreciate how serious the crisis actually was. ${ }^{131}$ Figure 1 shows the volume of those note and bond cases resulting in default judgments ${ }^{132}$ in Plymouth County ${ }^{133}$ between 1781 and 1786, preceding Shays' Rebellion.

As can be seen in Figure 1, the volume of cases resulting in default judgments skyrocketed from 1781 to 1784 in response to the recession, multiplying almost three and one-half times. Litigation volume declined, however, in 1785, though it increased somewhat in 1786 . There are two potential reasons for the decline in litigation in 1785 . First, as described earlier, the General Court in 1784 expanded the jurisdiction of justices of the peace from cases on matters involving less than $£ 2$ to cases on matters involving less than $£ 4$. This statute was likely to shift litigation to justices of the peace, reducing litigation in the common pleas courts. Second, the tight money conditions that began in 1781 and continued through 1784 are likely to have reduced the volume of available credit and, therefore, of

129. See Jonathan M. Chu, Debt Litigation and Shays's Rebellion, in IN DEBT TO SHAYS, THE BICENTENNIAL OF AN AGRARIAN REVOlution 81, 92 (Robert A. Gross ed., 1993) (describing how creditors were forced to sue debtors to pay their own debts during Shays' Rebellion).

130. See id.

131. For other data on the increase in litigation preceding Shays' Rebellion, see, for example, SZATMARY, supra note 4, at 29-30.

132. Figure 1 relies on the same data set used in Table 3. Figure 1 shows the volume of note and bonds cases that included a complete date of signing or sealing. The total volume of debt cases in each year, of course, was greater. The trends shown here, however, are likely to be similar to the trend in total volume of debt cases.

133. Although Plymouth was not central to Shays' Rebellion, litigation trends there were likely to mirror litigation trends in areas that were central to the Rebellion. Shays' Rebellion was a reaction to a widespread economic crisis affecting all of New England and, preceding the Rebellion, Plymouth's economic problems were similar to those of rural Massachusetts generally. See SZATMARY, supra note 4, at 58-59 (describing the geographical scope of Shays' Rebellion); Nelson, supra note 16, at 3 ("[T]hroughout the period [1686 to 1859] the county had a pattern of economic growth and change that mirrored that of Massachusetts as a whole."). In addition, Plymouth's courts were adjourned during the court closings of Shays' Rebellion, so the courts may have preempted protest by anticipating the Regulators' demands. The Regulator assaults on the courts began after the harvest in August 1786. See SZATMARY, supra note 4, at 58. The Plymouth County October 1786 and December 1786 sessions were adjourned to January 8, 1787 . See 10 PLYMOUTH COURT RECORDS, supra note 16, at 58-65. State militias began suppressing the Rebellion in January 1787, the month when the Plymouth Courts reopened. See TAYLOR, supra note 4 , at $158-59$. 
outstanding debt, reducing the set of obligations potentially subject to suit. $^{134}$

\section{Figure 1: Note AND Bond CASES Resulting IN DEFAUlt PRECEDING SHAYS' REBELLION}

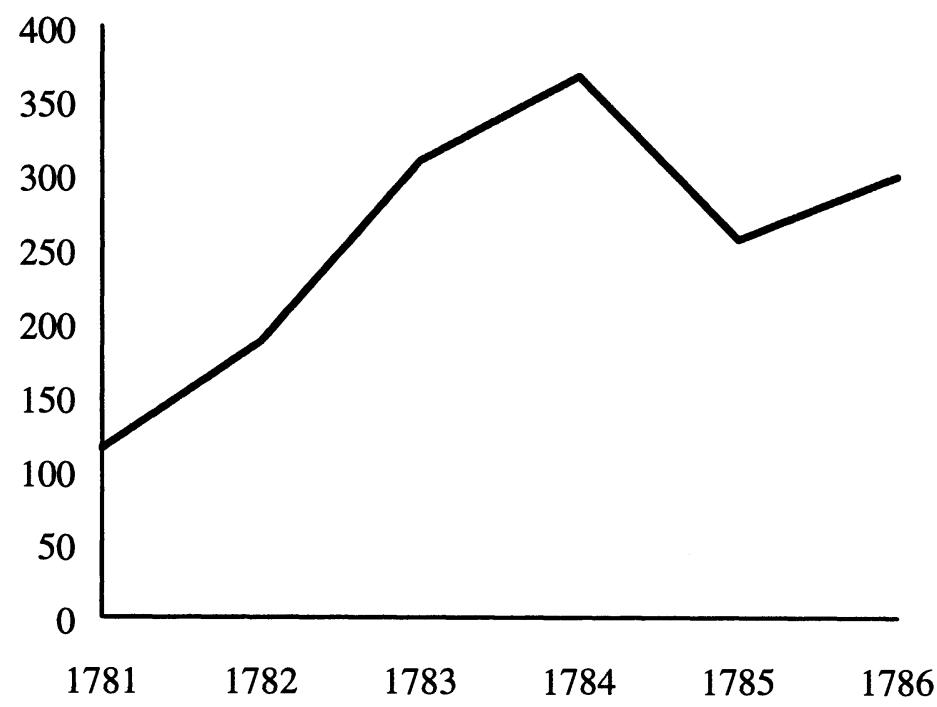

Figure 1, thus, shows through litigation statistics the impact of the deepening recession on credit after the Revolution. The increased litigation between 1781 and 1784 imposed the high costs of colonial courts more broadly on the population. Finally, Figure 1 indicates debt litigation rising again in 1786, approaching 1783 levels. In 1786, litigation volume was still three times greater than in 1781, imposing continuing judicial fee burdens on Massachusetts debtors.

It may be recalled that the principal empirical support for the debtrecording interpretation of litigation was a sharp increase in cases resulting in default judgments during the first half of the eighteenth century. ${ }^{135}$ Colonial legal scholars have interpreted this rise in litigation as evidence of

134. In addition, litigation volume may have been affected by a combination of other less distinctive events. The General Court increased taxes on judicial services in 1785 , though not by a large amount. See 1784-1785 Mass. Acts 458-62, ch. 18; TAYLOR, supra note 4, at 126. Taylor reports that economic conditions somewhat improved in 1785 , following unusually good crops in 1784. See id. at 125. In addition, in response to protests, the General Court suspended taxation in 1785 , though it imposed heavy poll taxes in 1786, perhaps explaining the rise of litigation that year. See id. at 126, 129.

135. See supra note 22 and accompanying text. 
commercialization and a prosperous economy. Shays' Rebellion suggests a contrasting interpretation of rising default judgments. If defaults are actual defaults, and not debt recording, then rising default levels signal widespread insolvency and possibly severe recession rather than economic prosperity.

\section{The Adoption of a Debt-Recording System in Response to Shays' Rebellion}

The protests immediately preceding Shays' Rebellion began in 1786. In response, the General Court swiftly enacted reform legislation. In July 1786 , acknowledging that it was the legislature's duty to provide "speedy" decisions "attended with as little expense to the citizens of this Commonwealth, as the nature of things will admit," the General Court passed legislation establishing procedures for submitting debt cases to arbitrators (called referees) for a fee of two shillings. ${ }^{136}$ The Shaysites were not mollified; court closings began in August 1786. In November, the General Court passed the Confession Act, ${ }^{137}$ effective January 1, 1787, requiring that all debt litigation commence before a justice of the peace where the debtor was to confess judgment. ${ }^{138}$ According to the Act, the parties were required to record the precise amount of the debt and the exact date the debt was due at the hearing. ${ }^{139}$ Once this process was completed, creditors could automatically foreclose on the debtors' possessions fifty days after the due date. ${ }^{140}$ If a debtor did not appear, a default judgment was to be entered. ${ }^{141}$

The principal purpose of the Confession Act was to encourage creditors to record their debts soon after the time the debt was executed. Thus, the Confession Act marks the moment when the Massachusetts courts established litigation as a recording device. Of course, the Confession Act had further purposes as well. It removed debt litigation from the courtsclearly a political response to the years of protest against the court system and the violent takeover of the courts in Shays' Rebellion. After the Confession Act, dispute over fees and liability were resolved soon after the

136. See 1786-1787 Mass. Acts 55-57, ch. 21.

137. 1786-1787 Mass. Acts 105-111, ch. 43. This Act was entitled “An Act for Rendering Processes in Law Less Expensive." See id.

138. See id. at 106-07. Matters involving issues of the title of real estate were excluded from the jurisdiction of the justices of the peace. See id. at 106.

139. For the forms provided by the General Court, see id. at 106-09.

140. See id. at 108. Another measure to keep litigation out of the courts was to require justices of the peace to encourage debtors who disputed the case to use arbitrators rather than to appeal the case to the common pleas court. See id. at 109. The Confession Act did not revise the fee schedule, so presumably fees remained at 30 pence. In February 1787, however, the General Court issued a new fee schedule that raised the fees of the justices of the peace. See 1786-1787 Mass. Acts 226-38, ch. 73.

141. See 1786-1787 Mass. Acts 108, ch. 43. 
time debts were executed: The courts no longer served as the institution for processing debt disputes; thus, the courts could no longer be the focal point of resentment.

The text of the Confession Act reveals that it was perceived by those who drafted it to serve as only a temporary resolution to the concerns raised by Shays' Rebellion. It was enacted for a limited term - "two Years, and no longer"-requiring explicit renewal in $1788 .{ }^{142}$ The General Court renewed the Act in 1788, but only for a four-year period. ${ }^{143}$ By June 1, 1792, however, the country was long out of the former recession, ${ }^{144}$ allowing litigation conditions to normalize. The General Court allowed the Confession Act to expire, permitting a reversion back to the 1784 law providing justices of the peace jurisdiction over cases concerning $£ 4$ or less. ${ }^{145}$ The Plymouth County records show that in the period 1792 to 1795 conditions were similar to those preceding the Rebellion: Cases originated in the common pleas, and median litigation timing was nearly identical to that before Shays' Rebellion. ${ }^{146}$

When did courts assume a debt-recording function? William Nelson shows that court fees were radically reduced by the dismantling of the British writ and fee system, a doctrinal development occurring gradually between 1790 and $1840 .{ }^{147}$ The law permitting creditors to obtain explicit security interests in the personal property of their debtors emerged in the period 1820 to $1830 .{ }^{148}$ Massachusetts enacted its first bankruptcy statute in 1800 , which, although in effect for only two years, was permanently reenacted in $1838 .{ }^{149}$

\section{CONCLUSION: REINTERPRETING THE ROLE OF COLONIAL COURTS IN COMMERCIAL TRANSACTIONS}

The empirical findings presented suggest a new interpretation of the colonial court system's role in creating conditions for economic advance. This Note analyzes three reasons why the interpretation of default

142. See id. at 111

143. See 1788-1789 Mass. Acts 131, ch. 67.

144. See MCCUSKER \& MENARD, supra note 34, at 63 tbl.3.4 (showing economic growth throughout the period 1789 to 1796 ).

145. In 1797, upon general conversion from pounds to dollars, an Act passed that explained that $£ 4$ was equivalent to $\$ 13.33$. See $1796-1797$ Mass. Acts 373 , ch. 21 .

146. In 1795, the median interval between execution and suit was 443 days, almost equal to the median during the period 1781 to 1786 (427 days).

147. See NELSON, supra note 21, at 72-88.

148. See id. at $253 \mathrm{n} .100$. For a comprehensive discussion of the legal history of secured transactions, see 1 GRANT GILMORE, SECURITY INTERESTS IN PERSONAL PROPERTY 24-25 (1965).

149. See Peter J. Coleman, Debtors and Creditors in America: Insolvency, IMPRISONMENT FOR DEBT, AND BANKRUPTCY, 1607-1900, at 50-51 (1974). 
judgments as evidence of the institutionalization of a debt-recording system is inadequate. First, examining court fees in relation to debt levels reveals that litigation was extremely costly and, in most cases, litigation purely to record debts was an undesirable strategy. Indeed, burdening debtors with court fees may have decreased creditors' chances of repayment. Second, evidence of actual litigation timing shows that creditors did not typically file suit immediately, as would be expected if creditors litigated for recording purposes. Third, the Regulators' proposals to institutionalize debt recording preceding Shays' Rebellion and the General Court's legal responses to those proposals are further evidence that such a system did not exist during the colonial period.

Thus, during the colonial period, Massachusetts courts did not provide the economic benefits that a debt-recording system, such as the modern UCC, achieves by reducing or eliminating uncertainty over collection. In the colonial period, creditors and debtors, as a general matter, incurred the costs of creditors' uncertainty about their priority with respect to other creditors, creditors' uncertainty about the nature of debtors' other debts, and the costs of litigating in an expensive system when creditors feared that they would not otherwise be repaid. Anecdotal evidence in historians' accounts suggests, indeed, that colonial creditors incurred great costs to obtain information about debtors' financial status and to keep any negative information secret from other creditors. As described by A.G. Roeber, court sessions were widely attended and, indeed, "Court days" were regional, popular events, in part, because they were the best time for creditors to see "who was recovering against whom and what their own roles might be at any given moment." ${ }^{150}$ Outside of court days, creditors worked to keep negative information about debtors' financial status secret, according to Harrington, because "every creditor hoped to be able to collect his debts before the insolvency of the debtor became generally known." ${ }^{151}$ Greater uncertainty reduces the supply of credit and increases its price. Thus, the absence of a debt-recording system in the colonial period reduced the supply of credit and increased interest rates, leading to lower levels of investment than would otherwise have been possible.

During times of recession, such as during Shays' Rebellion, however, the absence of a debt-recording and -securing system led to a climate of extreme uncertainty among creditors. The immediate effect of the absence of priority rules during the postwar recession was a race to the courts to claim any available assets. ${ }^{152}$ Skyrocketing litigation meant skyrocketing

150. See ROEBER, supra note 14, at 85 . For a description of "Court day" in Virginia, see id. at 73-95.

151. See HARRINGTON, supra note 66, at 119.

152. These are the conditions bankruptcy statutes of the 19th century were enacted to remedy. 
fees imposed on debtors. In essence, colonial court fees functioned as an insolvency tax. By means of this "tax," the colonial courts dealt debtors a severe blow at the worst possible time. The lack of a recording system reduced the supply of credit and increased interest rates universally, and equally important, worsened economic conditions during recessions. These problems characterized the many recessions faced before the Revolution as well as Shays' Rebellion.

How much did colonial courts affect economic conditions? It is impossible to quantify the costs of not having a debt-recording and -securing system during the colonial period. It may be recalled, however, that approximately three-fourths of noncriminal cases in the colonial period were debt-collection matters, so that, in terms of courts' function in the economy, the lack of a debt-recording system was highly important. ${ }^{153}$ This Note concludes, however, that the debt-recording interpretation of colonial law and its implications for the role of the courts in enhancing economic growth must be substantially qualified or rejected. 